\title{
Comparative Effect of Aqueous Extract of Psidium guajava Leaves and Arthemetar/Lumefantrine (coartem) on non-targeted parameters in Plasmodium berghei- Infected Mice
}

Shedrach Kanu ( $\nabla$ shedy4success@yahoo.com )

Alex-Ekwueme Federal University Ndufu-Alike

Jerius Ejeje

Alex-Ekwueme Federal University Ndufu-Alike

Nwabueze Elom

Alex-Ekwueme Federal University Ndufu-Alike

Chinedu Eleazu

Alex-Ekwueme Federal University Ndufu-Alike

Uket Obeten

Alex-Ekwueme Federal University Ndufu-Alike

\section{Research Article}

Keywords: Anti-malaria drugs, antioxidant enzymes, erythrocyte, parasite

Posted Date: February 28th, 2022

DOI: https://doi.org/10.21203/rs.3.rs-1367258/v1

License: (c) (1) This work is licensed under a Creative Commons Attribution 4.0 International License.

Read Full License 


\section{Abstract \\ Objective}

To study the effect of aqueous extract of Psidium guajava and arthemeter/lumefantrine (coartem) on non-targeted parameters in Plasmodium berghei-infected mice.

\section{Methods}

Twenty five mice (out of thirty mice weighing between 30 and $35 \mathrm{~g}$ ) were intraperitoneally infected with $0.2 \mathrm{ml}$ of $1 \times 10^{5} / \mathrm{ml}$ parasitized erythrocytes of Plasmodium berghei (NK 65 strain) and randomly grouped into six (G2-G6) with five (5) mice each. G1 (normal control) received distilled water and animal feed. G2 (parasite control) received $1 \mathrm{ml}$ of distilled water daily. Groups (G3-G6) were treated with $28 \mathrm{mg} / \mathrm{kg} \mathrm{b.w}$ of coartem, $200 \mathrm{mg} / \mathrm{kg}$ b.w, $400 \mathrm{mg} / \mathrm{kg}$ b.w and $600 \mathrm{mg} / \mathrm{kg}$ b.w of Psidium guajava extract respectively. Data were entered and analyzed using SPSS-21 statistical software. A $p<0.05$ was taken as statistically significant.

\section{Results}

The Psidium guajava aqueous extract revealed presence of saponins, alkaloids, tannins, terpenoids and flavonoids. All the groups treated with Psidium guajava aqueous extract showed a dose-dependent significant $(p<0.05)$ increase in percentage clearance rate of the malaria parasite, PCV, HB, and RBC count, antioxidant status, antioxidant enzymes activities and a significant $(p<0.05)$ decrease in MDA level, ALP, AST and ALT activities as against the coartem treated and the parasite control groups.

\section{Conclusion}

Aqueous extract of Psidium guajava leaf could be useful in the treatment of diseases and symptoms caused by plasmodium parasites, especially berghei species with milder side effects than coartem.

\section{Introduction}

Unfortunately, most of the anti-malaria drugs like artemisinine combination therapy exert their antiplasmodial effect with a concomitant release of free radicals (2). These free radicals are both friends and foes to the host metabolic processes- Friend in the sense that the parasite is destroyed, but in return endangers host cells and tissues leading to necrosis and inflammation especially the red blood cells and hepatocytes (3).

In search of a better treatment option, phytochemicals from plants origin have been proven over the years to be highly potent as anti-malaria agents (due their antioxidant activities) together with their chemo- 
protective effects against ailments (4). Guava is a plant in the myrtle family (Myrtaceae) genus Psidium. Extracts from guava leaves or bark have been implicated in therapeutic mechanisms against cancer, bacterial infections, inflammation and pain $(4,5,6)$. Essential oils from guava leave have anti-cancer activity in vitro (7).

Guava leaves are used in folk medicine as a remedy for diarrhea and fever, malaria; the bark extracts acts as antimicrobial and as an astringent agent (8). Guava leaves and bark are used in traditional medicine for management of diabetes (9). Phytochemical analyses of guava leaf revealed the presence of alkaloids, anthocyanins, carotenoids, essential oils, fatty acids, flavonoids (especially quercetin), lectins, phenols, saponins, tannins, triterpenes, and vitamin C (10).

\section{Material And Methods}

\section{Collection of plant materials and authentication}

The leaves of Psidium guajava were obtained from the Alumni Garden of Alex Ekwueme Federal University Ndufu Alike on 20th October, 2020. The leaves were identified and authenticated at the Department of Plant Science, Ebonyi State University, Abakaliki, Nigeria. The voucher specimen of the plant is available. A sample of the plant portion was deposited at the Departmental Herbarium for future purpose.

Preparation of aqueous extract of Psidium guajava

The leaves of Psidium guajava were air-dried at room temperature. The air-dried leaves were ground to powder using electric blender. Exactly $50 \mathrm{~g}$ of the sample was soaked in $1000 \mathrm{~mL}$ of de-ionised water for 24 hours at room temperature, under occasional shaking. It was then filtered using a Whatmann filter paper (No.1). The filtrate was concentrated to dryness using a rotary evaporator at $45^{\circ} \mathrm{C}$ to obtain the aqueous crude extract and the extract was stored in the fridge at $4{ }^{\circ} \mathrm{C}$ until needed.

\section{Experimental Animals}

A total of thirty mice of both sexes weighing between 30 to $35 \mathrm{~g}$ were acquired from Nigerian Institute of Medical Research, Lagos. They were acclimatized for seven days before use. The animals were housed in a plastic/wire gauze animal cage and were placed on standard feed and free access to water ad libitum.

\section{Experimental Design}

Thirty mice weighing between 30 and $35 \mathrm{~g}$ were used for this work. Twenty five mice were intraperitoneally infected with $0.2 \mathrm{ml}$ of $1 \times 10^{5} / \mathrm{ml}$ parasitized erythrocytes of Plasmodium berghei (NK 65 strain) and randomly grouped into six (G2-G6) with five (5) mice each while the remaining five mice served as the normal control and all the mice in the respective groups were treated as follows:

Group 1(Normal control) received distilled water and animal feed 
Group 2 (Parasitic control) received $1 \mathrm{~mL}$ of distilled water daily

Group 3: Treated with $28 \mathrm{mg} / \mathrm{kg}$ b.w of coartem orally

Group 4: Treated with $200 \mathrm{mg} / \mathrm{kg}$ b.w. of aqueous extract of Psidium guajava leaf (AEPGL) orally

Group 5: Treated with $400 \mathrm{mg} / \mathrm{kg}$ b.w. of aqueous extract of Psidium guajava leaf (AEPGL) orally

Group 6: Treated with $600 \mathrm{mg} / \mathrm{kg}$ b.w. of aqueous extract of Psidium guajava leaf (AEPGL) orally

The animals were maintained at a room temperature of $24 \pm 2^{0} \mathrm{C}$ with 12 hours light/dark cycle, under the principles and guidelines of the Nigeria Council on Animal Care as outlined in Guide for the care and use of Laboratory Animals'.

\section{Determination of biochemical parameters}

\section{Liver enzyme biomarkers}

The activities of Aspartate amino transferase (AST), Alanine amino transferase (ALT), and Alkaline phosphatase (ALP) were assayed according to the method of Reitman and Frankel (17).

\section{Estimation of antioxidant parameters}

Serum ascorbic acid, Superoxide Dismutase (SOD), Glutathione Peroxidase (GPx), Catalase (CAT) activities and malondialdehyde (MDA) were assessed by the method of Arthur and Boyne (20), Paglia and Valentine (21), Aebi, et al. (22) and Walin et al. (23) respectively.

\section{Determination of hematological parameters}

Pack Cell Volume (PCV), Hemoglobin concentration (HB), and Red blood cell count (RBC) were determined following the procedure described by Ochei et al. (18). While the Total White blood Cell counts (WBC), lymphocyte count, and eosinophil count were determined by hemocytometry method as described by Cheesbough (19).

\section{Statistical analysis}

The result of the replicates were pooled and expressed as Mean \pm Standard deviation and One-way analysis of variance (ANOVA) followed by Tukey's test were used to check the level of significance at $p<$ 0.05 .

\section{Results}

Table 1: Effect of aqueous extract of Psidium guajava leaf on percentage clearance of plasmodium berghei in mice 
The result (table 1) below showed a dose-dependent clearance percentage of the aqueous extract compared to the parasite group and the coartem treated group, though a greater percentage was recorded in coartem treated group.

\begin{tabular}{llc}
\hline $\mathbf{S} / \mathbf{N}$ & Groups & Percentage (\%) clearance \\
\hline 1 & NC & 0.00 \\
2 & PC & 14.24 \\
3 & $28 \mathrm{mg} / \mathrm{kg}$ coartem & 82.10 \\
4 & $200 \mathrm{mg} / \mathrm{kg} \mathrm{AEPGL}$ & 48.95 \\
5 & $400 \mathrm{mg} / \mathrm{kg} \mathrm{AEPGL}$ & 53.95 \\
6 & $600 \mathrm{mg} / \mathrm{kg} \mathrm{AEPGL}$ & 65.59 \\
\hline
\end{tabular}

Key: NC = Normal control, PC $=$ Parasitic control and AEPGL $=$ Aqueous extract of Psidium guajava leaf .

\section{Table 2: Antioxidants and antioxidant enzymes concentration of the various treatment groups}

There was a significant $(p<0.05)$ decrease in serum vitamin C (ascorbic acid), GPx and CAT of the parasite control group and coartem treated group compared to the normal control and the extract treated groups. There was no statistically significant $(p>0.05)$ difference in the activities of SOD among all the groups except $600 \mathrm{mg} / \mathrm{kg}$ AEPGL which was significant ( $p>0.05$ ) compared to parasite control group. There was a dose-dependent increase in serum vitamin C (ascorbic acid), GPx, CAT and SOD among the extract treated groups though not statistically significant $(p>0.05)$ 


\begin{tabular}{ccccccc}
\hline Parameters $/$ NC & PC & $28 \mathrm{mg} / \mathrm{kg}$ & $200 \mathrm{mg} / \mathrm{kg}$ & $400 \mathrm{mg} / \mathrm{kg}$ & $600 \mathrm{mg} / \mathrm{kg}$ \\
Group & & & coartem & AEPGL & AEPGL & AEPGL \\
\hline VIT C (mg/dl) & $1.178 \pm 0.03$ & $0.74 \pm 0.08^{\mathrm{a}}$ & $0.73 \pm 0.10^{\mathrm{a}}$ & $1.13 \pm 0-05^{\mathrm{b}}$ & $1.12 \pm 0.02^{\mathrm{b}}$ & $2.15 \pm 0.02^{\mathrm{bc}}$ \\
& & & & & & \\
$\mathrm{CAT}(\mathrm{U} / \mathrm{mg})$ & $3.59 \pm 0.34$ & $2.61 \pm 0.11^{\mathrm{a}}$ & $2.45 \pm 0.05^{\mathrm{a}}$ & $4.03 \pm 0.02^{\mathrm{ab}}$ & $4.54 \pm 0.01^{\mathrm{ab}}$ & $5.77 \pm 0.04^{\mathrm{bc}}$ \\
& & & & & & \\
$\mathrm{SOD}(\mathrm{U} / \mathrm{mg})$ & $11.66 \pm 0.02$ & $11.00 \pm 0.07$ & $11.41 \pm 0.03$ & $11.27 \pm 0.09$ & $11.60 \pm 0.05$ & $12.99 \pm 0.19^{\mathrm{b}}$ \\
& & & & & & \\
GPX (U/mg) & $31.12 \pm 0.07$ & $28.63 \pm 0.04^{\mathrm{a}}$ & $29.97 \pm 0.43^{\mathrm{a}}$ & $31.75 \pm 0.29^{\mathrm{b}}$ & $32.70 \pm 0.05^{\mathrm{bc}}$ & $33.50 \pm 0.38^{\mathrm{bc}}$
\end{tabular}

Results are presented as Mean \pm SD. Values with different superscripts indicate significant difference at $\mathrm{P}<0.05$.

Key: $\mathrm{NC}=$ Normal control, $\mathrm{PC}=$ Parasitic control, AEPGL $=$ Aqueous extract of Psidium guajava leaf, $\mathrm{U} / \mathrm{mg}=$ units per $\mathrm{mg}$ of enzyme proteins.

Table 3: Effect of aqueous extract of Psidium guajava leaf on lipid peroxidation of plasmodium bergheiinfected mice.

The result of table 3 indicated high level of lipid peroxidation in both parasite control and coartem treated groups unlike the extract treatment groups. Interestingly, the extract induced a dose-dependent protective effect against lipid peroxidation when compared to the parasite control and coartem treated groups

\begin{tabular}{lll}
\hline $\mathbf{S} / \mathbf{N}$ & \multicolumn{1}{c}{ Groups } & MDA (mg/d) \\
\hline 1 & $\mathrm{NC}$ & $2.69 \pm 0.52$ \\
2 & $\mathrm{PC}$ & $4.70 \pm 0.35^{\mathrm{a}}$ \\
3 & $28 \mathrm{mg} / \mathrm{kg}$ coartem & $4.33 \pm 0.23^{\mathrm{a}}$ \\
4 & $200 \mathrm{mg} / \mathrm{kg} \mathrm{AEPGL}$ & $2.94 \pm 0.24^{\mathrm{bc}}$ \\
5 & $400 \mathrm{mg} / \mathrm{kg} \mathrm{AEPGL}$ & $2.86 \pm 0.23^{\mathrm{bc}}$ \\
6 & $600 \mathrm{mg} / \mathrm{kg} \mathrm{AEPGL}$ & $2.75 \pm 0.23^{\mathrm{bc}}$ \\
\hline
\end{tabular}


Results are presented as Mean \pm SD. Values with different superscripts indicate significant difference at $\mathrm{P}<0.05$.

Key: $\mathrm{NC}=$ Normal control, PC $=$ Parasitic control, AEPGL = Aqueous extract of Psidium guajava leaf,

Table 4: Effect of aqueous extract of Psidium guajava leaf on hematological parameters of plasmodium berghei infected mice.

The result of table 4 reveals significant $(p<0.05)$ reduction in PCV, HB and RBC levels in parasite control and coartem treated groups when compared to the extract treated groups and normal control. Increased level of WBC, eosin, and lymph was recorded in parasite control group when compared to the other treatment groups and the normal control. However, the aqueous extract caused a dose-dependent ameliorative effect on most of the hematological parameters except on eosin when compared to the parasite control group.

Parameters/Groups NC PC $28 \mathrm{mg} / \mathrm{kg}$ coartem $200 \mathrm{mg} / \mathrm{kg}$ AEPGL $\quad 400 \mathrm{mg} / \mathrm{kg}$ AEPGL $600 \mathrm{mg} / \mathrm{kg}$ AEPGL

\begin{tabular}{lrrrrrr} 
PCV (\%) & $56 \pm 1.23$ & $38 \pm 2.48^{\mathrm{a}}$ & $35.5 \pm 2.63^{\mathrm{a}}$ & $47.35 \pm 1.32^{\mathrm{bc}}$ & $47.75 \pm 1.33^{\mathrm{bc}}$ & $47.85 \pm 2.93^{\mathrm{bc}}$ \\
& & & & & & \\
HB (mg/d1) & $18.65 \pm 0.39$ & $12.65 \pm 0.80^{\mathrm{a}}$ & $11.83 \pm 0.86^{\mathrm{a}}$ & $15.93 \pm 0.45^{\mathrm{bc}}$ & $15.70 \pm 1.50^{\mathrm{bc}}$ & $15.78 \pm 0.98^{\mathrm{bc}}$ \\
& & & & & \\
RBC (X1012/L) & $7.94 \pm 0.35$ & $5.54 \pm 0.21^{\mathrm{a}}$ & $5.8 \pm 0.38^{\mathrm{a}}$ & $7.98 \pm 0.18^{\mathrm{bc}}$ & $8.00 \pm 0.02^{\mathrm{bc}}$ & $7.95 \pm 0.46^{\mathrm{bc}}$ \\
& & & & & \\
WBC (X109/L) & $9.45 \pm 0.40$ & $10.80 \pm 0.25^{\mathrm{b}}$ & $9.60 \pm 0.59^{\mathrm{a}}$ & $9.79 \pm 0.16^{\mathrm{a}}$ & $9.68 \pm 0.11^{\mathrm{a}}$ & $9.10 \pm 0.30^{\mathrm{a}}$ \\
Eosin (\%) & $1.25 \pm 0.25$ & $5.00 \pm 0.40^{\mathrm{a}}$ & $1.75 \pm 0.47^{\mathrm{b}}$ & $2.50 \pm 0.29^{\mathrm{b}}$ & $2.35 \pm 1.11^{\mathrm{b}}$ & $2.00 \pm 0.41^{\mathrm{b}}$ \\
Lymph (\%) & $67.25 \pm 1.38$ & $68.75 \pm 0.63^{\mathrm{a}}$ & $57.5 \pm 2.63^{\mathrm{b}}$ & $61.5 \pm 4.64^{\mathrm{b}}$ & $59.50 \pm 1.12^{\mathrm{b}}$ & $58.75 \pm 0.75^{\mathrm{b}}$ \\
\hline
\end{tabular}

Results are presented as Mean $\pm S D$. Values with different superscripts indicate significant difference at $\mathrm{P}<0.05$.

Key: $\mathrm{NC}=$ Normal control, $\mathrm{PC}=$ Parasitic control, $\mathrm{AEPGL}=$ Aqueous extract of Psidium guajava leaf.

Table 5: Effect of aqueous extract of Psidium guajava leaf on liver enzymes of plasmodium berghei infected mice

The result of table 5 indicates increased activities of the liver enzymes (AST, ALT and ALP) on parasite control group and coartem treated group unlike the other treatment groups. The aqueous extract reversed 
the increased activities of those liver enzymes in a non-dose-dependent order.

Parameters Groups NC PC $28 \mathrm{mg} / \mathrm{kg}$ coartem $200 \mathrm{mg} / \mathrm{kgAEPGL} \quad 400 \mathrm{mg} / \mathrm{kgAEPGL} 600 \mathrm{mg} / \mathrm{kgAEPGL}$

$\begin{array}{lllllll}\text { AST (U/L) } & 95.00 \pm 2.0 & 113.80 \pm 4.73^{\mathrm{a}} & 101.00 \pm 3.08^{\mathrm{a}} & 77.50 \pm 4.79^{\mathrm{bc}} & 88.89 \pm 4.55^{\mathrm{bc}} & 96.50 \pm 4.79^{\mathrm{bc}} \\ \text { ALT (U/L) } & 80.00 \pm 5.78 & 126.30 \pm 2.39 & 106 \pm 5.72^{\mathrm{a}} & 90.75 \pm 4.15^{\mathrm{b}} & 90.55 \pm 6.33^{\mathrm{b}} & 80.00 \pm 9.13^{\mathrm{b}} \\ \mathbf{A L P}(\mathbf{U} / \mathbf{L}) & 11.84 \pm 1.22 & 16.25 \pm 1.09^{\mathrm{a}} & 10.81 \pm 1.29^{\mathrm{b}} & 9.60 \pm 0.70^{\mathrm{b}} & 9.75 \pm 5.35^{\mathrm{b}} & 9.84 \pm 3.36^{\mathrm{b}}\end{array}$

Results are presented as Mean \pm SD. Values with different superscripts indicate significant difference at $\mathrm{P}<0.05$.

Key: NC = Normal control, PC = Parasitic control, AEPGL = Aqueous extract of Psidium guajava leaf.

\section{Discussion}

Malaria is a major public health problem in Sub-Sahara region with wide-ranging hematological and biochemical alterations. This disease is caused by parasitic protozoan, the Plasmodium species and it poses a severe public health problem which is characterized by increased parasitemia, anemia, reduced availability of nitric oxide, and increased systemic expression of white blood cells etc. (46).

Phytochemicals are functional foods derived from plants which possess antioxidant, nutraceuticals, phytonutrients, anti-nutrients and phytotoxins properties etc. The presence of alkaloids, saponin flavonoids and tannins in AEPGL proves the medicinal value of the plant. Flavonoids have been documented to possess anti-oxidant activities, anti-inflammatory activities, anti-cancer activities and antimicrobial properties (47). Tannins are a group of polymeric phenolic compounds which have the ability to inactivate and kill microorganisms. Their pharmacological effects are used in the treatment of varicose ulcers, hemorrhoids, minor burns etc. Alkaloids serve as local anesthetic and stimulants with both antibacterial and antimalarial activities (e.g. quinine). Saponins are glycosides found widely in plants that have detergent, antioxidant, antiinflammatory, antiapoptosis and immunostimulant properties (48).

In this study, the percentage clearance of parasitemia was determined for all the groups, a significant ( $p<$ 0.05 ) increase in percentage clearance of malaria parasite after treatment compared with the baseline among all the treated groups was recorded. With comparison to the extract treated groups and the coartem treated group, the percentage malaria parasite clearance $(82.10 \%)$ was significantly $(p<0.05)$ higher than that of the aqueous extract of Psidium guajava leaf (AEPGL) treated groups (table 1 ). However, the AEPGL treated groups showed a dose-dependent clearance rate with the highest concentration (1000 mg/kg b.w) having the highest percent of malaria parasite clearance $(65.59 \%)$ compared to the parasite control group (14.28\%). It is therefore evident that the chemical drug (coartem) 
is more potent in clearing plasmodium parasite than the extract. This result is consonance with findings of other researchers $(24,25,26)$.

As shown in table 2 , there was a significant $(p<0.05)$ decrease in serum vitamin $C$ (ascorbic acid) of the parasite control group and coartem treated group compared to the normal control and the extract treated groups. This decrease in serum vitamin $\mathrm{C}$ level among those groups is a symbol of oxidative stress due to action of the malaria parasite and effect of the drug metabolism on P450 enzymes (33). The AEPGL treated group showed a significant $(p<0.05)$ increase of serum ascorbic acid level when compared to the normal control and parasite control. This is possibly because of the potentiating ability of antioxidant property of vitamin $\mathrm{C}$ by the extract. Hence, scavenging and chelating reactive oxygen species produced by the body's defense mechanisms (parasite control) and during drug metabolism (coartem treated group) (34).

Oxidative stress biomarkers including SOD, GPx, GST, CAT, and GSH are accountable for guarding the living system against oxidative stress through the maintenance of physiological concentration of free radicals (49). Antioxidant enzymes specifically Glutathione peroxidase (GPx), Catalase (CAT) and Superoxide dismutase (SOD) activities in serum were assayed. Although there was no statistically significant $(p>0.05)$ difference in the activities of SOD among all the groups (table 3 ), but there was a significant $(p<0.05)$ decrease in GPx and CAT activities of the parasite control group and the standard drug (coartem) treated group compared to the normal control group (table 3). Superoxide dismutase transforms superoxide radicals via the dismutation process to hydrogen peroxide. CAT converts hydrogen peroxide into water whereas GPx detoxifies lipid peroxides (49). The observed decrease in SOD activity is a confirmation of oxidative stress in both the parasite control group and the standard drug treated group. In contrast, there was a significant $(p<0.05)$ increase in GPx and Catalase activities among the extract treated groups when compared to the parasite control group and the standard drug treated group. The increased antioxidant enzyme activities could be attributed to the high antioxidant contents of AEPGL and the synergetic action of the likely bioactive compounds in the extract which must have mitigated the generation of free radicals and supplied reducing equivalent to the enzymes $(38,49)$.

Systemic expression of serum malondialdehyde (MDA) has been categorized as a biomarker of lipid peroxidation due to free radicals attack on membrane lipids of macromolecules. The accumulation of free radical trigger lipid peroxidation (assayed as MDA), a practice that encourages lipids of the cell membrane experiences catabolism, resulting in organ impairment, probably due to breakdown of the polyunsaturated fatty acids in the liver and kidney. There was a significant $(p<0.05)$ increase in serum malondialdehyde (MDA) of the parasite group compared to the normal control and the extract treated groups as presented (in table 4). However, no statistically significant $(p>0.05)$ difference on the concentration of MDA between the standard drug (coartem) treated group and the parasite control group. This could be attributed to increased rate of lipid peroxidation occasioned by increased free radical generation incurred on the course of drug metabolism by the body system. Interestingly, a momentous reduction in the level of serum MDA was observed among the extract treated groups in a dose-dependent order compared to standard drug (coartem) treated group, parasite control and normal control groups. 
This could be as a function of the phytochemicals present in AEPGL playing their antioxidant and pharmacological effects thus ameliorating lipid peroxidation among the extract treated groups. The observed results in this study corroborate the findings of other previous research $(35,36,37)$.

Pack cell volume (PCV), hemoglobin concentration (HB) and red blood cell count (RBC) are hematological indices for the evaluation of anemia (39). The result of this study (table 4) showed a significant $(p<0.05)$ decrease in PCV, HB, and RBC of both the parasite control group and the standard drug (coartem) treated group compared to the normal control group. Off course, lipid peroxidation arising from free radicals and the metabolic effects of the drug are possible reasons for this decrease (36). In contrast, a significant ( $<$ 0.05 ) increase in these parameters was observed among the extract treated group compared to the former groups. The combined effect of the various antioxidants such as flavonoids, tannins and alkaloids present in the extract could be responsible for mopping up the free radicals thereby guarding the cell membranes of the red cells against lipid peroxidation and hemolysis (40).

Studies have shown that white blood cell (WBC) total count and WBC differential counts are indices for evaluating the level of infection $(41,42)$. Although there was no statistically significant $(p<0.05)$ increase in total WBC and lymphocytes among the parasite control group compared to the normal control group but its eosinophil count demonstrated a significant $(p<0.05)$ increase when compared to the normal control group. This increased eosinophil in response to malaria infection is in line with the report of Kotepui, et al and Kurtzhals et al $(43,44)$. Interestingly, a significant $(p<0.05)$ decrease in the eosinophil count of all the treated groups (G3-G6) compared to parasite control group was recorded. This confirms the capability of the extract against infectious diseases, probably due to the existence of tannins, flavonoids and alkaloids (48).

Alkaline phosphatase (ALP) is a useful tool used in the detection of renal damage in a disease condition. Enzyme activity in the organs is employed as a means of confirming the toxic nature of consumed xenobiotics. ALP is a membrane-bound enzyme and has the highest concentration in the kidney, and is found in substantial amounts once the cell membrane ruptures or burst (49).

Aspartate amino transferase (AST) and Alanine amino transferase (ALT) are two of the intracellular enzymes whose activities in serum increases when there is tissue or cellular necrosis and inflammation especially within the red blood cells and hepatocytes $(27,28)$. The result of this study showed a significant $(p<0.05)$ increase in serum ALP, AST and ALT activities of the parasite control group and coartem treated group compared to the normal control group (table 5). This increase could be linked to necrosis and hemolysis caused by parasite infection in the hepatocytes and the red blood cells $(29,30)$. Conversely, those negative effects were protected against by the AEPGL as recorded in the extracted treated groups.

Unlike AST and ALT, there was no significant $(p>0.05)$ difference in ALP between the coartem treated and extract treated groups compared to the normal control, possibly because there was no hepatobilliary obstruction or bone disease (27). But a statistically significant result was obtained in the parasite control group which is indication of renal damage probably due to oxidative stress accumulation in those 
animals. The excellent performance of AEPGL in normalizing this adverse effect of parasite infection in those mice could be linked to the existence of antioxidants as well as phytochemicals in the extract. This observation is in consonance with the reports of other previous researchers $(49,32,32)$.

\section{Conclusion}

From the results of this study, it was concluded that though both coartem and aqueous extract of $P$. guajava leaf (AEPGL) specifically destroyed the Plasmodium berghei parasites, the AEPGL demonstrated a more positive effect on non-target parameters than the coartem. Hence, AEPGL is apparently a safer option than arthemeter/lumefantrine as an antimalarial having milder side effects, easily accessible and affordable especially for the rural dwellers.

\section{Declarations}

\section{Availability of Data}

All data will be made available upon reasonable request

\section{Author contribution}

Concept development: Kanu Shedrach. Experimental work: Kanu Shedrach and Ejeje Jerius. Data analysis: Uket Obeten. Data Interpretation: Kanu Shedrach , Uket Obeten, Ejeje Jerius, Eleazu Obeten and Nwabueze Elom. Writing: Kanu Shedrach and Ejeje Jerius. All authors read and approved the final manuscript.

\section{Funding}

This research was collectively funded by the authors.

\section{Ethics approval}

The study protocol was reviewed and ethical clearance was obtained from the Ethics Committee of Faculty of Biological sciences, Alex Ekwueme Federal University, Ndufu-Alike Ikwo Ebonyi State, Nigeria.

\section{Conflict of interest}

The authors declare no competing interest.

\section{References}

1. Cássio, B., Antonio, C., Athaid, D., Wagner, W., Andreus, R., Aline F., Mardelson N., Breno, W., José A., Wagner J. and Mônica da S., (2015) Side Effects of Chloroquine and Primaquine and Symptom Redution in Malaria Endemic Area (Mâncio Lima, Acre, Brazil). interdisciplinary perspective on infectious diseases, 2015(15) 1-7. 
2. Antoine, T., Fisher, N., Amewu, R., O'Neill, P.M., Ward, S.A. and Biagini, G.A. (2014) Rapid kill of malaria parasites by artemisinin and semisynthetic endoperoxides involves ROS dependent depolarization of the membrane potential. Journal of Antimicrobial Chemotherapy, 69:1005- 1016.

3. Reginald, A., Kavishe, J.B., Koenderink, M.A. (2017) Oxidative stress in malaria and artemisinin combination therapy: Pros and Cons. The FEBS Journal, 284 (16): 2579-2591.

4. Chen, K., Hsieh, C., Peng, C., Hsieh, L., Hsiu, M., Chiang, H., Huang, K., Peng, R. (2007) Brain derived metastatic prostate cancer DU-145 cells are effectively inhibited in vitro by guava (Psidium guajava L.) leaf extracts. Nutrition and Cancer, 58(1): 93-106.

5. Mahfuzul, H.D., Bari, M.L., Inatsu, Y., Juneja, V.K., Kawamoto, S. (2007) Antibacterial activity of guava (Psidium guajava L.) and Neem (Azadirachta indica A. Juss.) extracts against foodborne pathogens and spoilage bacteria. Food-borne Pathogens and Disease, 4(4): 481-488.

6. Ojewole, J.A. (2006) Antiinflammatory and analgesic effects of Psidium guajava Linn. (Myrtaceae) leaf aqueous extract in rats and mice. Methods and Findings in Experimental and Clinical Pharmacology, 28(7): 441-446.

7. Ghasi, S., Egwuibe, C., Achukwu, P. and Onyeanusi, J. (2011). Assessment of Medical benefit in the folkloric use of Bryophyllum pinnatum leaf among the Igbos of Nigeria for the treatment of hypertension. African Journal of Pharmacy and Pharmacology, 5(1):83-92.

8. Kaljee, L.M., Thiem V.D., von Seidlein L., Genberg B.L. , Canh D.G., Le H., Minh T.T., Thoa Le T.K, Clemens J.D. and Trach, D.D. (2004). Healthcare Use for Diarrhoea and Dysentery in Actual and Hypothetical Cases, Nha Trang, Viet Nam. Journal of Health, Population and Nutrition, 22 (2): 139149

9. Oh, W.K., Lee C.H. and Lee, M.S. (2005) Antidiabetic effects of extracts from Psidium guajava. Journal of ethnopharmacology, 96(3): 411-415.

10. Begum, S., Hassan, S.I., Siddiqui, B.S., Shaheen, F., Ghayur, M.N., Gilani, A.H. (2002) Triterpenoids from the leaves of Psidium guajava. Phytochemistry. 61(4):399-403.

11. Sara, A., Rosa E. M., Engels B., Cesar S., Lester, G., Marcel F., Suzeth G., Alejandra, P., Angel, M. \& Gustavo, F. (2018) G6PD deficiency, primaquine treatment, and risk of haemolysis in malaria-infected patients. Malaria Journal, 17(415) 15-25

12. OECD Guidance document on acute oral toxicity (2000) Enviromental health and safety monograph series on testing and Assessment, 24:15-24

13. Kokate, C.K. (2005) Practical Pharmacognosy.Vallabh prakashan, Delhi, pp 107-111.

14. Khandelwal, K.R. (2003) Practical Pharmacognosy Techniques and Experiments. $9^{\text {th }}$ Edn, Nirali Prakashan, Pune.

15. Lorke, D. (1983) A new approach to practical acute toxicity testing. Archive of Toxicology, 54:275-87.

16. Ryley, J.F. and Peters, W. (1970). The antimalarial activity of some quinolone esters. American Tropical Medical Parasitology, 84:209-222. 
17. Reitman, S. and Frankel, S. (1957) Determination of Aspertate amino transferase, American Journal of Clinical pathology, 28:56

18. Ochei, J. and Kolhatkar A. (2000) Procedure for red blood cell count. Medical laboratory Science Theory and Practice. $10^{\text {th }}$ edn. New Delhi,India: TataMcGraw Hill. p 240

19. Cheesbrough, M. (2010). District laboratory practice. $2^{\text {nd }}$ edition. Cambridge University Press, New York. Pp.335-345.

20. Arthur, J. and Boyne, R. (1985) Superoxide dismutase and glutathione peroxidase activities in neutrophils from selenium deficient and copper deficient cattle, Life science,36:(16)1569-1575

21. Aebi, H. (1984) Catalase in vitro. Methods in Enzymology, 105: 121-126,

22. Wallin, B., Rosengren, B., . Shertzer, H.G. and Camejo, G. (1993) Lipoprotein Oxidation and Measurement of Thiobarbituric Acid Reacting Substances Formation in a Single Microtiter Plate: Its Use for Evaluation of Antioxidants. Analytical Biochemistry, 208 (1):10-15,

23. Paglia, D. E. and Valentine, W.N. (1967) Studies on the quantitative and qualitative characterization of erythrocyte glutathione peroxidase Journal of Laboratory and Clinical Medicine, 70(1):158-69.

24. Ofori-Attah, K., Oseni Lateef A., Quasie O., Antwi S. and Tandoh M. () A Comparative Evaluation of invivo Antiplasmodial Activity of Aqueous Leaf Exracts of Carica Papaya, Azadirachta Indica, Magnifera Indica and the Combination Thereof using Plasmodium Infected Balb/C Mice. international journal of applied biology and pharmaceutical technology, 3(3)373-379

25. Awoibi, K., Akio B., Obiajunwa, O., Nwanjo U., Nwosu B. (2019) Toxicological and Antiplasmodial Suppressive Activities of Ethanolic Extracts of Orange (Citrus sinensis)peels Grape (Citrus paradisi and Guava (Psidium guajava)Leaves in Albino Rats. International Journal of Engineering Science Invention (IJESI), 8(8)37-44

26. Erhirhie, E., Ikegbune C., Okeke, A., Onwuzuligbo, C., Madubuogwu, N., Chukwudulue, U. \& Okonkwo, O. (2021) Antimalarial herbal drugs: a review of their interactions with conventional antimalarial drugs, Clinical Phytoscience, 7(4):1-10

27. Chatterjea, M. and Rana, S. (2012) Text Book of Medical Biochemistry. Enzymes and isoenzymes of Clinical importance. J.P brothers Medical Publishers Ltd, New Delhi India. Eight Edition. pp637-644

28. Maduka, I. and Emeka, N. (2008) Effects of malaria parasitemia on liver enzyme tests. Oxidative stress in malaria parasite-infected erythrocytes: host-parasite interactions. International Journal of Tropical Medicine, 3(3):49-52

29. David wilson. (2011) Clinical Veterinary Advisor: The Horse. Elsevier, 1st Edition.

30. Douglas, N., Anstey N, Buffet P, Poespoprodjo J, Yeo T. and White, N. (2012) The anaemia of Plasmodium vivax malaria. Malaria Journal, 11:135

31. Usunobun, U., Osaigbovo, j. and Okolie. (2020) Hepatoprotective and antioxidant effect of rhaphiostylis beninensis ethanol root extract on carbon tetrachloride (ccl4)-induced hepatotoxicity and oxidative stress. Animal research international, 17(2): 3781 - 3789 
32. Gabriele, P., Natasha I., Mariapaola C., Giovanni P., Federica M., Vincenzo A., Francesco, S., Domenica A, Alessandra, B. (2017) "Oxidative Stress: Harms and Benefits for Human Health", Oxidative Medicine and Cellular Longevity, 2017 (13):345-355

33. Becker, K., Tilley L, Vennerstrom J., Roberts D, Rogerson, S. and Ginsburg, H.(2004) International Journal of Parasitology, 34(2):163-89.

34. Adagu, I.S. and Warhurst, DC (2001) Plasmodium falciparum: linkage disequilibrium between loci in chromosomes 7 and 5 and chloroquine selective pressure in Northern Nigeria. Parasitology, 123 (3): 219-224.

35. Mohamad, N., BandayaF., Ahmad L.F., RasoolaM. and Rashida, A. (2017) Use of antioxidants reduce lipid peroxidation and improve quality of crossbred ram sperm during its cryopreservation, elsevier, $74: 25-30$

36. Patrícia., Aleksandro S., Carolina K.T, Francine C. P., Juliana F. C., Marciélen P., Mauren E. P, Sílvia G. M. and Sonia, T. L., (2009) Lipid peroxidation associated with anemia in rats experimentally infected with Trypanosoma evansi. journal of vetrinary parasitology, 168 (1) 41-46

37. Nwonuma, C.O., Osemwegie, O.O., Alejolowo, E.O., Irokanulo, A.F. Olaniran, Fadugba, O.O. and Ojo, O.A. (2021). Antioxidant and the ameliorating effect of Allium cepa (Onion) fortified feed against potassium bromate induced oxidative damage in Wistar rats, Toxicology Reports, (8): 759-766,

38. Sandro, P., Bruno, A., Gomes, M.E., Ferreira, S., Ana C. M., Gonçalves, Paula S., Laurindo, O. C., Thyago C., Vilhena, M., and Michael, D.G. (2012) Oxidative Stress in Malaria. Malaria journal, 13 (12): 1634616372

39. Suchita V. Ingale, Milind P. Ullewar, Vikas C. Ingale, Jayshree J. Upadhye, (2017) Evaluation of anaemia. International Journal of research in medical science, 5 (10):4481-4485

40. Asgary, S., Naderi, G, and Askari, N. (2005) Protective effect of flavonoids against red blood cell hemolysis by free radicals. Experimental and clinical cardiology, 10(2): 88-90.

41. Kotepui, M., Bhukdee D., Phun Phuech, Phiwklam N., Chaowanee Chupeerach, and Suwit Duangmano (2015) Effects of Malaria Parasite Density on Blood Cell Parameters. PLoS One. 10(3): e0121057

42. Lyrad, K., Riley, MD. and Jedda, R. (2015) Evaluation of Patients with Leukocytosis.. American Family Physician, 92(11):1004-1011

43. Kotepui, M, Bhukdee P., Nuoil P., and Kwuntida U. (2018). The Hematological Alteration of Patients Parasitized by Plasmodium vivax. Walailak Journal of Science \& Technology, 15(9): 637-643

44. Kurtzhals, J.A., Reimert, C.M., Tette, E., Dunyo, S.K., Koram, K.A., Akanmori, B.D., Nkrumah, F.K.. and Hviid, L. (1998) Increased eosinophil activity in acute Plasmodium falciparum infection-association with cerebral malaria, Clinical Experimental Immunology 112 (2): 303-307.

45. Luis, H. C., Polarat, W., Günter, W., Marco, A., Mercader, 1., Gary, M., Brittenham, Sornchai, L. and Victor R. G. (1999) The eosinophilic response and haematological recovery aftertreatment for Plasmodium falciparummalari. Tropical Medicine and International Health, 4(7): 471-475.

46. Sirak, S., Fola, A.A., Worku, L., and Biadgo, B. Malaria parasitemia and its association with lipid and hematological parameters among malariainfected patients attending at Metema Hospital, Northwest 
Ethiopia. Pathology and Laboratory Medicine International, 2016, 8:43-50.

47. Uchewa, O.O., Okoronkwo, C.A., Igwe, E.C., Egwu, A.J. and Okoronkwo, S.O. The Protective Role of Aqueous Extract of Ficus Vogelii (Fv) on the Lower Reproductive Organs (Vagina and Cervix) of Lead Acetate Induced Toxicity of an Adult Female Wistar Rats. American Journal of Research Communication, 2017, 5(11): 56-70.

48. Kassa, B. and Mesay, S. Phytochemical Constituents and Physicochemical Properties of Medicinal Plant (Moringa Oleifera) Around Bule Hora, Chemistry and Materials Research, 2014, 6(7): 201.

49. Ajiboye, B.O., Oyinloye, B.E., Essien, P.E., Oniakinn S.A., Ojo, O.A., and Kappo, P.A. (2020). Ameliorative potential of Sterculia tragacantha aqueous extract on renal gene expression and biochemical parameters in streptozotocin-induced diabetic rats. Journal of Pharmaceutical Investigation, https://doi.org/10.1007/s40005-020-00506-8.

50. Aimmanas, A., Pranee, C., Pat, R. and Pranee, C. (1995). Toxicity study of Psidium guajava Linn. Leaves. AGRIS, 1995, 37(4): 289-304. 